\section{Petrusha 0., Daschynska D., Shulika A.}

\title{
DEVELOPMENT OF THE MEASUREMENT METHOD OF POROSITY OF BAKERY PRODUCTS BY ANALYSIS OF DIGITAL IMAGE
}

Хлібобулочні вироби являються невід'ємною складовою частиною харчування, тому вимірювання їх якості формує умови більш стабільної діяльності підприємства. Одним із таких показників є пористість, яка визначає структуру виробу, об'єм, рівень засвоюваності. Розмір пор хліба залежить від сорту використаного борошна чи їх суміші, рівня належної практики проведення технологічних процесів. Об'єктом дослідження є метод вимірювання пористості хлібобулочних виробів на базі аналізу цифрових зображень зрізів хлібобулочної продукиї.

Використання методу відцифровування зрізів продукцї із наступним аналізом отриманих зображень дає можливість швидко проводити вимірювання пористості. Порядок визначення пористості полягає y співставленні плош пікселів зображення хліба. Запропонований метод не вимагає додаткових витрат i може бути реалізований з використанням офісного сканеру. Поруч з иим перспективним є використання даного методу для вимірювання пористості дрібноштучних булочних виробів, для яких пористість теж є критерієм якості продукиії.

В ході проведених досліджень були експериментально встановлені поправочні коефічієнти для групи виробів, які виготовляються із різних видів борошна:

1,71 - для виробів із борошна вищого гатунку;

1,44 - для виробів із пшеничного борошна першого гатунку;

0,61 - із суміші житньо-пшеничного борошна.

Визначені коефічієнти дають змогу перейти від виміряної величини пористості до звичної - тієї, яка зазначена у нормативній документащії.

Проведене порівняння точності стандартного методу вимірювання пористості із запропонованим методом за аналізом цифрових зображень зрізів вказує на можливість використання останнього у щоденній виробничій діяльності. Запропонований метод також може бути вжитий для вимірювання пористості дрібноштучних хлібобулочних та кондитерських борошняних виробів, для яких у зв'язку із відсутністю дієвого методу показник пористості не нормується, хоча і характеризує якість продукиї.

Ключові слова: пористість хлібобулочних виробів, цифрове зображення, прикладна програма IтаgеJ, точність аналізу.

\section{Introduction}

The rapid development of science and technology in the world is expanding the capabilities of all spheres of management, including the food industry that requires the use of innovative technologies, improving working and production conditions, a variety of products and the introduction of perfect methods for determining product quality.

To date, meeting the needs of the population in highquality food is one of the main socio-economic problems.

The bakery industry is one of the leading and most labor-intensive branches of the food industry, because it carries out the task of producing essential products.

The development of the bakery industry is carried out in different directions. Their contribution is made by manufacturers and suppliers of ingredients, equipment, packaging [1]. Specialists of various industries are improving technology, so that as a result the consumer is satisfied with the quality of grain products. Bread is in great demand among people, and therefore requires careful monitoring.
Porosity is one of the main indicators that determines the quality of bakery products and characterizes their structure, volume and level of digestibility.

A standardized method for determining the porosity of bakery food products is the method using a Zhuravlev device.

However, the use of the standard method for smallbaked bakery products is due to the lack of the possibility of obtaining a notch from buns. At the same time, the porosity index is no less important for this group of products, since it characterizes the quality of the used raw materials, the proper manufacturing practice of introducing technological processes.

The advantage of this method is the increased accuracy of calculating the total porosity, and the disadvantage is the complexity of manufacturing the samples of the instrument for carrying out the tests.

The problem of the quality of bread and confectionery products is closely related to the problem of control. Therefore, the development of a method for determining porosity is relevant, since bakery products are an integral 
part of its diet of any person. The assortment of such food products is growing rapidly, and therefore requires careful monitoring in connection with the demands of consumers.

\section{The object of research and its technological audit}

The object of research is a method for measuring the porosity of bakery products based on the analysis of digital images of slices of bakery products.

Products having a porous structure belong to a large group of products that are manufactured by food industry institutions and public catering establishments. It includes chocolate, sausage products, confectionery products, presented by cupcakes, cookies, marshmallows, rolls, halva, gingerbread and others. The porous structure, of course, is most characteristic of bakery products and determines their quality.

The porosity of the product is the fraction of the pore volume in the total product volume, usually expressed as:

$$
P=V_{\text {por }} / V
$$

where $P$ - porosity, \%; $V_{\text {por }}$ - pore volume, $\mathrm{cm}^{3} ; V$ - volume of non-porous material together with pores, $\mathrm{cm}^{3}$.

Quite often, the structural characteristics, namely the pore size, their size distribution, pore volume, specific surface are united by the term «porous body texture». Porous bodies are widely distributed in nature and are very important for assessing the quality of certain foods and especially bakery and confectionery.

However, not for all objects of the food industry and only for certain groups are there objective, reliable, reproducible and accurate methods for measuring the porosity index. Existing methods have a high duration, require additional reagents and have a number of other drawbacks.

\section{The aim and objectives of research}

The aim of research is development of a methodology for determining the structural characteristics of bread porosity, as an indicator of the quality of the main food product of the population. To achieve this aim, it is necessary to implement the following tasks:

1. To carry out approbation of the method for determining the porosity of bakery products from the normalized value of porosity by analyzing the digital image.

2. To set the correction coefficients for the porosity determination by the proposed method.

\section{Research of existing solutions of the problem}

The simplest method for evaluating porosity is organoleptic [1, 2]. At the same time, special attention is paid to the pore size of the bakery product cut, and also the uniformity of pore distribution of different sizes over the cross section is established. The porous structure of the body is a heterogeneous system of the solid phase and the gas phase distributed in it, the ability to distribute evenly the gas formed as a result of fermentation. This structure depends on the elastic characteristics of the test itself, therefore, when evaluating the porosity, the thickness of the pore walls should be analyzed [3].
A significant advantage of this method of research is its efficiency, but it also has disadvantages - the subjectivity of such definition, because it directly depends on the abilities of the researcher.

The Ukrainian standardized method for determining the porosity of bakery food products is the method using the Zhuravlev device [4]. This method involves preparing the product, obtaining a notch from the bread crumb, followed by weighing and performing the appropriate calculations. It should be noted that such calculations use a standard notch volume equal to $27 \mathrm{~cm}^{3}$. Moreover, the actual volume of the metal cylinder, by means of which a recess is obtained, may deviate from such clearly defined value. Limited use of the standard method for small-baked bakery products is due to the lack of the possibility of obtaining a notch from buns.

Today, there are several ways to determine the porosity of bakery products. One of them is the method [5]. This method of determination includes the following order of work: in the test sample, a seizure is made, the pore volume in which is determined by impregnating it with an inert liquid (kerosene or xylitol). After that, it is weighed on an analytical balance and the mass of the inert liquid is determined. Further, the porosity is calculated using inert liquid mass values, inert liquid density and cavity volume. The advantage of this method is increased accuracy of calculating the total porosity, and the disadvantage is the complexity of manufacturing the samples of the instrument for carrying out the tests.

In [6-10], studies are carried out on the use of digital methods for image analysis of sections of prototypes of various products. For the wide use of this method, it is necessary to establish how one can go from the set value to the porosity in percent specified in the standards.

\section{Methods of research}

Modern technologies have become an integral part of life. The use of computers, mobile phones and other gadgets for work, communication, entertainment has become indispensable and even ordinary. Such inventions are designed to facilitate and improve our lives. The range of their use is distributed in various industries, including food.

The developed method involves obtaining the actual digital image of a porous slice of a sample bakery product for which a variety of equipment is used: web cameras, digital cameras, flatbed scanners. The latter device has an important number of advantages, namely high image quality, at low cost, automatic adjustment of parameters and calibration of the characteristics of the acquired images, the ability to scan images with high image resolution [4].

The methodology should provide a clearly defined procedure. To determine the porosity of food products, a unified flowchart is developed, depicted in Fig. 1, and a methodology for internal use is developed.

The method is realized on the basis of obtaining a digital image by scanning the section of the investigated object. The method involves scanning a slice of the bread crumb on a scanner with an optical resolution of 300 dpi (Fig. 2). The digital image obtained in this way was introduced into the special program ImageJ, written in the Java programming language, developed by the scientists of the National Institutes of Health (USA) for the general public of scientists [3]. 


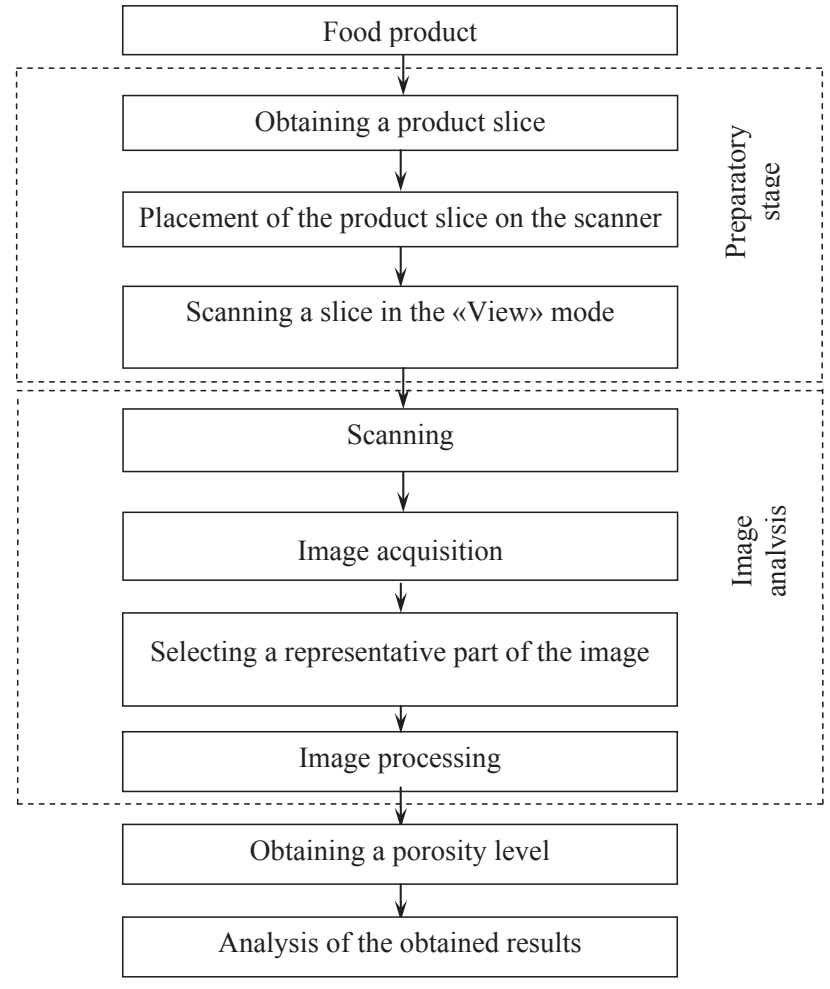

Fig. 1. Scheme of implementation of the method for determining the porasity of food products using the «Electronic Eye» type system

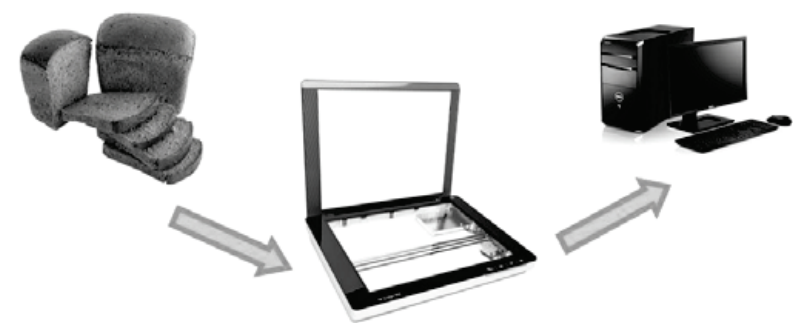

Fig. 2. Steps for determination by scanning

The program allows to automate photo processing, which first corrects the image, then formats it into shades of gray and divides the areas into dark (pores) and light (the mass of the non-porous material) (Fig. 3)

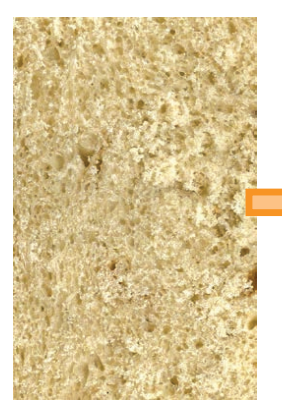

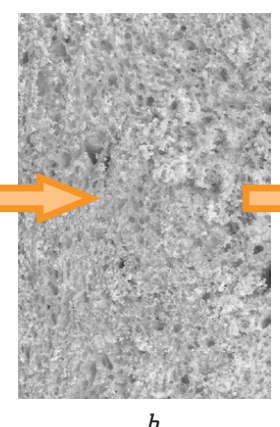

$b$

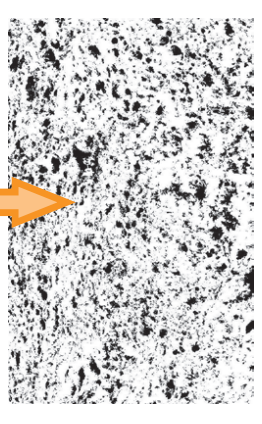

Fig. 3. The stages of image preparation:

$a$ - scanning; $b$ - color information reset; $c$ - tresholding (sifting)

Further processing is reduced to the calculation of the area of ellipses, equivalent in this indicator to each pore [6]. With a known scan extension, it is possible to easily move from the dimensions in pixels to the traditional units of pore sizes in percent.

The suggested method allows to carry out research more objectively and with greater accuracy, which is especially important when comparing the results of the investigated objects. In the case of comparing the developed method with the standard method using the Zhuravlev device, it should be noted that the innovative method for determining porosity is much shorter, the possibility of saving digital images is noted. A special advantage of the method for determining the porosity using the sensor type «Electronic Eye» is the possibility of its use for small items, from which it is not possible to make a notch for the standard method.

\section{Research results}

To test the method, studies were conducted to determine the porosity by a standard method using the Zhuravlev device and the proposed method using the possibility of using digital technology.

The assortment of bakery products is determined primarily by the type of flour used for their production. For research, bread was selected from wheat flour of the highest grade - a loaf, bread from wheat flour of the first grade and bread from a mixture of rye and wheat flour. During the experiment, tenfold repeatability of the studies was performed. In the data below, the averaged results of the studies are presented.

Next to the instrumental determination of the porosity of the products, a sensory analysis of the bread crumb was carried out. This characteristic is given in Table 1.

Table 1

Characteristics of organoleptic indicators of bakery products

\begin{tabular}{|c|c|c|c|}
\hline \multirow{2}{*}{ Indicator } & \multicolumn{3}{|c|}{ Characteristic of the indicator } \\
\hline & Loaf & Wheat bread & Ukrainian bread \\
\hline $\begin{array}{c}\text { Crumb } \\
\text { condition }\end{array}$ & $\begin{array}{l}\text { baked, elastic, mois- } \\
\text { ture to the touch, } \\
\text { without traces of } \\
\text { impurities }\end{array}$ & $\begin{array}{l}\text { baked, elastic, barely } \\
\text { moisture to the touch, } \\
\text { without traces of } \\
\text { impurities }\end{array}$ & $\begin{array}{l}\text { baked, elastic, } \\
\text { without traces } \\
\text { of impurities }\end{array}$ \\
\hline $\begin{array}{l}\text { Porasity } \\
\text { structure }\end{array}$ & $\begin{array}{c}\text { pores small and } \\
\text { medium, distributed } \\
\text { evenly }\end{array}$ & $\begin{array}{l}\text { pores are small and } \\
\text { medium, thin-walled, } \\
\text { distributed fairly } \\
\text { evenly }\end{array}$ & $\begin{array}{l}\text { pores are small, } \\
\text { thin-walled, dis- } \\
\text { tributed evenly }\end{array}$ \\
\hline $\begin{array}{l}\text { Crumb } \\
\text { color }\end{array}$ & light colored & light colored & $\begin{array}{l}\text { light brown, } \\
\text { without burnt }\end{array}$ \\
\hline $\begin{array}{l}\text { Crumb } \\
\text { chewing }\end{array}$ & $\begin{array}{l}\text { tender enough, well } \\
\text { chewed }\end{array}$ & $\begin{array}{l}\text { tender enough, well } \\
\text { chewed }\end{array}$ & $\begin{array}{l}\text { rather tender, } \\
\text { slightly dry, well } \\
\text { chewed }\end{array}$ \\
\hline
\end{tabular}

According to the data given in Table 1 it can be seen that all the studied samples correspond to the requirements of normative documents. The characterization of the crumb condition indicates the correctness of the introduction of the technological process and is evaluated as meeting the technical requirements of the standard.

In the process of method approbation an important issue was the determination of the conversion factor for products of the respective types of products. The essence of this correction coefficient lies in the fact that when scanning a section of an article, to obtain the area of the pores is obtained without taking into account its geometric features (Fig. 4). The treatment takes into account the 
average pore diameter, which leads to a further change in the porosity value $[10,11]$.
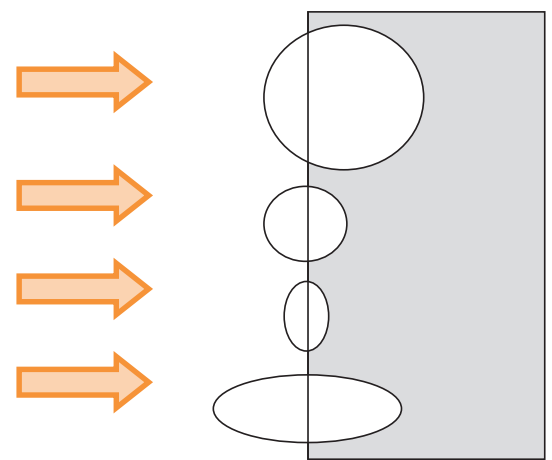

Fig. 4. The scheme of comparison of the scanned roundness of the pore to its geometric characteristics

In porosity studies using the Zhuravlev device, the porosity was determined by the volume of the notch of $27 \mathrm{~cm}^{3}$ and the volume of the recess was measured in parallel (by determining the parameters of the recess with a caliper) and also received a digital image of cutting bread with a flatbed scanner and a digital camera.

The average values of the results of determination of the porosity index for the loaf are shown in Table 2 .
The digit of the section of the test sample is sampled, from the part of the product which was then obtained by excavating the Zhuravlev instrument.

According to the presented data, it can be concluded that the use of the standard volume indicator is not entirely correct, since the deviation is between $0.1 \%$ and $0.8 \%$. That is, depending on the state of the crumb, namely its elasticity, the difference in the accepted standard value of the groove volume can cause deviations in the accuracy of the measured results.

The average porosity value determined after the Zhuravlev instrument is $74.1 \%$, respectively, for the standard volume of the notch and $74.6 \%$ for the measurement with the notch volume.

Processed digital images give underestimated porosity values, as expected. In accordance with this, the correction coefficient $\mathrm{k}_{1}$ is calculated, the average value of which is 1.71 for the loaf.

The average porosity value for the method using a sensor system of the «electronic eye» type is found to be $74.3 \%$.

The use of a digital camera for this method gives slightly higher values of porosity, with the next logical reduction of the correction factor. The porosity value for this variant is $73.8 \%$.

A similar order of research is carried out for products: wheat and Ukrainian bread, presented in Table 3, 4.

Table 2

The data of studies of bread porosity

\begin{tabular}{|c|c|c|c|c|c|c|c|c|c|}
\hline $\begin{array}{c}\text { No. of ex- } \\
\text { periment }\end{array}$ & $\begin{array}{c}\text { Notch } \\
\text { mass, g }\end{array}$ & $\begin{array}{c}\text { Porasity of the } \\
\text { Zhuravlev device, \% }\end{array}$ & $\begin{array}{c}\text { Porosity of the Zhuravlev device ac- } \\
\text { cording to the standard notch depth, \% }\end{array}$ & $\begin{array}{c}\text { Scanning } \\
\text { porosity, \% }\end{array}$ & $\begin{array}{c}\mathrm{k} 1, \\
\text { units }\end{array}$ & $\begin{array}{c}\text { Calculated } \\
\text { porosity, \% }\end{array}$ & $\begin{array}{c}\text { Photo po- } \\
\text { rosity, \% }\end{array}$ & $\begin{array}{c}\mathrm{k} 2, \\
\text { units }\end{array}$ & $\begin{array}{c}\text { Calculated } \\
\text { porosity, \% }\end{array}$ \\
\hline 1 & 9.2253 & 74.4 & 73.9 & 44.5 & 1.67 & 76.1 & 54.5 & 1.36 & 78.5 \\
\hline 2 & 9.1110 & 74.1 & 74.2 & 43.3 & 1.76 & 74.0 & 48.5 & 1.53 & 69.8 \\
\hline 3 & 9.6061 & 73.4 & 72.8 & 43.4 & 1.69 & 74.2 & 53.2 & 1.40 & 74.5 \\
\hline 4 & 8.6240 & 76.4 & 75.6 & 42.5 & 1.73 & 72.7 & 50.2 & 1.48 & 72.3 \\
\hline
\end{tabular}

The data of studies of Ukrainian bread porosity

\begin{tabular}{|c|c|c|c|c|c|c|c|c|c|}
\hline $\begin{array}{l}\text { No. of ex- } \\
\text { periment }\end{array}$ & $\begin{array}{c}\text { Notch } \\
\text { mass, g }\end{array}$ & $\begin{array}{l}\text { Porasity of the } \\
\text { Zhuravlev device, \% }\end{array}$ & $\begin{array}{l}\text { Porosity of the Zhuravlev device ac- } \\
\text { cording to the standard notch depth, \% }\end{array}$ & $\begin{array}{c}\text { Scanning } \\
\text { porosity, \% }\end{array}$ & $\begin{array}{c}\mathrm{k} 1, \\
\text { units }\end{array}$ & $\begin{array}{l}\text { Calculated } \\
\text { porosity, \% }\end{array}$ & $\begin{array}{l}\text { Photo po- } \\
\text { rosity, \% }\end{array}$ & $\begin{array}{c}\mathrm{k} 2, \\
\text { units }\end{array}$ & $\begin{array}{l}\text { Calculated } \\
\text { porosity, \% }\end{array}$ \\
\hline 1 & 12.0685 & 69.7 & 65.9 & 49.5 & 1.42 & 70.3 & 58.9 & 1.18 & 69.5 \\
\hline 2 & 10.8400 & 70.2 & 69.4 & 47.5 & 1.48 & 70.3 & 73.9 & 0.95 & 70.2 \\
\hline 3 & 9.9061 & 70.6 & 72.0 & 49.7 & 1.42 & 70.5 & 51.4 & 1.37 & 70.4 \\
\hline 4 & 12.4556 & 70.1 & 64.8 & 49.3 & 1.44 & 71.0 & 50.3 & 1.39 & 69.9 \\
\hline 5 & 10.9169 & 71.2 & 69.1 & 48.3 & 1.47 & 71.0 & 52.3 & 1.36 & 71.1 \\
\hline 6 & 12.1524 & 69.3 & 65.6 & 46.8 & 1.52 & 71.1 & 56.1 & 1.27 & 71.2 \\
\hline
\end{tabular}

Data on the porosity of Ukrainian bread

\begin{tabular}{|c|c|c|c|c|c|c|c|c|c|}
\hline $\begin{array}{l}\text { No. of ex- } \\
\text { periment }\end{array}$ & $\begin{array}{l}\text { Notch } \\
\text { mass, g }\end{array}$ & $\begin{array}{l}\text { Porasity of the } \\
\text { Zhuravlev device, \% }\end{array}$ & $\begin{array}{l}\text { Porasity of the Zhuravlev device ac- } \\
\text { cording to the standard notch depth, \% }\end{array}$ & $\begin{array}{l}\text { Scanning } \\
\text { porosity, \% }\end{array}$ & $\begin{array}{l}\mathrm{k} 1 \\
\text { units }\end{array}$ & $\begin{array}{l}\text { Calculated } \\
\text { porosity, \% }\end{array}$ & $\begin{array}{l}\text { Photo po- } \\
\text { rosity, \% }\end{array}$ & $\begin{array}{l}\mathrm{k} 2, \\
\text { units }\end{array}$ & $\begin{array}{l}\text { Calculated } \\
\text { porosity, \% }\end{array}$ \\
\hline 1 & 17.7290 & 48.4 & 46.6 & 89.0 & 0.54 & 48.1 & 36.9 & 1.31 & 48.3 \\
\hline 2 & 16.0679 & 54.2 & 51.6 & 94.0 & 0.58 & 54.5 & 36.8 & 1.47 & 54.1 \\
\hline 3 & 16.3190 & 54.3 & 50.9 & 95.4 & 0.57 & 54.4 & 39.5 & 1.37 & 54.1 \\
\hline 4 & 14.0316 & 59.8 & 57.7 & 93.9 & 0.64 & 60.1 & 40.9 & 1.46 & 59.7 \\
\hline 5 & 13.6910 & 60.6 & 58.8 & 93.3 & 0.65 & 60.7 & 43.9 & 1.38 & 60.6 \\
\hline 6 & 14.0484 & 59.6 & 57.7 & 87.2 & 0.68 & 59.3 & 45.0 & 1.32 & 59.4 \\
\hline
\end{tabular}


For wheat bread, the average porosity was $70.2 \%$ when measuring the volume of the notch and $67.8 \%-$ when using the standard volume of the notch in the calculations (Table 3).

Assortment of bakery products, produced from wheat flour of the first grade, inherent finely porous structure. In this case, the geometric shape of the pore is more approximate to the spherical shape, as indicated by a decrease in the magnitude of the correction factor to 1.44 units.

The best convergence was shown by methods for determining the porosity of wheat bread using the Zhuravlev device and the proposed method using a digital image with values of $70.2 \%$ and $70.5 \%$. Other methods with a standard volume of crumb extraction and the use of a digital camera are $67.8 \%$ and $70.6 \%$.

The experimental determination of the porosity of Ukrainian bread is given in Table 4 and is also confirm the possibility of using this method. This is confirmed by the convergence of the results-an identical porosity value of $56.2 \%$ for methods using the Zhuravlev device and using an electronic eye sensor system.

The correction factor for Ukrainian bread is less than one unit -0.61 units. That is due to the peculiarities of production of this product, namely the material used for the mixture of rye-wheat flour.

For products made from a mixture of rye and wheat flour, the porosity value determined after the Zhuravlev instrument with a calculation for the standard volume of the notch was somewhat understated and amounted to $53.9 \%$. But the method of using a digital image with a digital camera has significantly inflated the results $-65.1 \%$, not corresponding to the actual value of the porosity of the product, can be caused by the peculiarity of the color of Ukrainian bread when the digital image is received by the camera, the distance to the investigated object.
To summarize the studies, a statistical analysis of the data is carried out. At the same time, for each array of experiments, the existence of a gross error is established [12].

To assess the results of the analysis, an average value of the results of parallel determinations characterized by the value of the confidence interval boundaries is established, as well as reproducibility and accuracy.

The procedure for calculating the accuracy of the studies is carried out in the following order: calculation of the variance, standard deviation of the mean result, confidence interval value, confidence error (calculated using the $t$-test - Student's test). Further, the accuracy of the analysis was calculated as the ratio of the confidence error to the true, i. e., mean.

The carried out calculations with the accuracy of the analysis are presented in Table 5 .

In accordance with the received data it should be noted that for the bakery products from the wheat flour of the highest and the first grade the highest accuracy (i. e., low accuracy of the analysis) had the proposed method. And for Ukrainian bread, the accuracy is somewhat less in relation to the standard method using the Zhuravlev instrument with the measurement of the notch volume.

The accuracy of the analysis resulting in the statistical calculation is the value of the accuracy value (Fig. 5).

According to the presented data, the deviation of the accuracy of the study is clearly visible when using the standard volume of the notch - for wheat bread.

When comparing the proposed method with digital image processing, the best way is obtaining an image by a flatbed scanner. Even the low value of the analysis accuracy for Ukrainian bread is due not to the reproducibility of this method with the production of a digital image by photographing a chamber for bakery products from a mixture of rye and wheat flour.

Table 5

Accuracy analysis data

\begin{tabular}{|c|c|c|c|c|c|}
\hline Methodology & $\begin{array}{l}\text { Dispersions } \\
S^{2}, \text { units }\end{array}$ & $\begin{array}{l}\text { The standard deviation of } \\
\text { the average result is } S_{x \prime} \text { units }\end{array}$ & $\begin{array}{l}\text { Confidence er- } \\
\text { ror, } E \text {, units }\end{array}$ & $\begin{array}{l}\text { Confidence } \\
\text { interval, units }\end{array}$ & $\begin{array}{c}\text { Analysis } \\
\text { accuracy, } \Delta, \%\end{array}$ \\
\hline \multicolumn{6}{|c|}{ Loaf } \\
\hline Porosity according to Zhuravlev notches, \% & 1.69 & 0.65 & 2.07 & $74.57 \pm 2.07$ & 2.77 \\
\hline Porosity according to Zhuravlev device of notch V, \% & 1.31 & 0.57 & 1.82 & $74.16 \pm 1.82$ & 2.46 \\
\hline Porosity is calculated using a flatbed scanner, \% & 1.12 & 0.35 & 0.81 & $74.45 \pm 0.81$ & 1.09 \\
\hline Calculated porosity using a digital camera, \% & 1.29 & 0.38 & 0.87 & $74.50 \pm 0.87$ & 1.17 \\
\hline \multicolumn{6}{|c|}{ Wheat bread } \\
\hline Porosity according to Zhuravlev notches, \% & 0.46 & 0.28 & 0.71 & $70.19 \pm 0.71$ & 1.01 \\
\hline Porosity according to Zhuravlev device of notch V, \% & 7.81 & 1.14 & 2.93 & $67.80 \pm 2.93$ & 4.32 \\
\hline Porosity is calculated using a flatbed scanner, \% & 0.36 & 0.23 & 0.56 & $70.53 \pm 0.56$ & 0.79 \\
\hline Calculated porasity using a digital camera, \% & 0.54 & 0.26 & 0.62 & $70.44 \pm 0.62$ & 0.88 \\
\hline \multicolumn{6}{|c|}{ Ukrainian bread } \\
\hline Porosity according to Zhuravlev notches, \% & 22.55 & 1.94 & 4.98 & $56.15 \pm 4.98$ & 8.88 \\
\hline Porosity according to Zhuravlev device of notch V, \% & 24.08 & 2.00 & 5.15 & $53.89 \pm 5.15$ & 9.56 \\
\hline Porosity is calculated using a flatbed scanner, \% & 23.40 & 1.97 & 5.08 & $56.17 \pm 5.08$ & 9.00 \\
\hline Calculated porosity using a digital camera, \% & 1.08 & 0.37 & 0.87 & $62.51 \pm 0.87$ & 1.39 \\
\hline
\end{tabular}




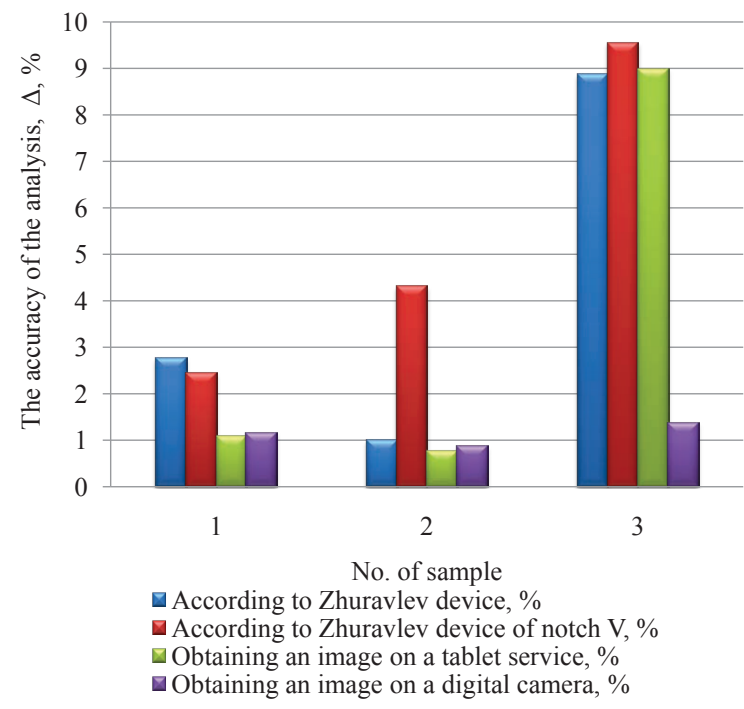

Fig. 5. Accuracy of analysis of porosity determination of bakery products: 1 - Loaf; 2 - Wheat bread; 3 - Ukrainian bread

\section{SWOT analysis of research results}

Strengths. Strength of the proposed method are:

- exclusion of the weighing operation;

- exclusion of the use of additional equipment;

- allows to autodocument the analysis results.

Weaknesses. The disadvantages of the proposed method include the presence in the working skills of working with computers and office equipment.

Opportunities. The prospect of using the proposed method is determination of the porosity of small-baked bakery and flour confectionery.

Threats. Application of the proposed method will require enterprises to conduct preliminary studies on the establishment of correction factors for the respective products.

\section{Conclusions}

1. Approbation of the method for determining the porosity of bakery products from wheat flour of higher and first grades and from a mixture of rye and wheat flour was carried out by parallel measurement of the porosity of these products by a standard procedure. As a result, it is confirmed that the method can be used to measure the porosity of bakery products from the normalized index of the previous adjustment of the correction factor. In the case of confectionery products, the measured value of the porosity should be guided by the proposed method, since there are no methods for determining the true value of this value.

2. Correction coefficients for determination of porosity are experimentally found. So, the ratio of the established values of porosity to the standard method and the correction factor proposed for the wheat flour of the premium grade is 1.71 , of the wheat flour of the first grade -1.44 and of the mixture of rye and wheat flour -0.61 . The following measurement of the porosity of these products requires multiplying the correction factor by a certain porosity value by analyzing the digital image of the product slice.

\section{References}

1. The effect of improver on dough rheology and bread properties / Horvat D. et al. // $4^{\text {th }}$ International Congress Flour bread '07. $6^{\text {th }}$ Croatian Congress of Cereal Technologists. Opatija, 2007. P. 37-42.

2. Microstructure, textural and sensorial properties of durum wheat bread as affected by yeast content / Lampignano V. et al. // Food Research International. 2013. Vol. 50, No. 1. P. 369-376. doi:10.1016/j.foodres.2012.10.030

3. Ferreira T., Rasband W. ImageJ User Guide: IJ 1.42r. 2012. 185 p.

4. Metody opredeleniya fiziko-khimicheskikh pokazateley kachestva khleba: poristost' // Khlibopekarska i kondyterska promyslovist Ukrainy. 2010. Vol. 9 (70). P. 16-17.

5. Sposib vyznachennia zahalnoi porystosti khlibobulochnykh i biskvitnykh vyrobiv: Patent No. 43027 UA, MPK A21D13/08 Safonova O. M., Chudik Yu. V., Zakharenko V. O. Appl. No. 2000127262. Filed: 18.12.2000. Published: 15.11.2001, Bul. No. 10.

6. Tuomisto C. The Effects of Alpha-amylase, Ascorbic Acid and Low Pressure during Mixing on the Texture of Bread Crumb. Image Analysis and Measurements of Physical Texture. Technology, Food Processing and Biotechnology, 2013. 47 p.

7. High resolution pore size analysis in metallic powders by X-ray tomography / Heim K. et al. // Case Studies in Nondestructive Testing and Evaluation. 2016. Vol. 6. P. 45-52. doi:10.1016/ j.csndt.2016.09.002

8. Scanning electron microscopy and swelling test of shrimp shell chitosan and chitosan-RGD scaffolds / Mandacan M. C. et al. // Journal of Physics: Conference Series. 2017. Vol. 884. doi:10.1088/1742-6596/884/1/012047

9. Quantitative analysis of cheese microstructure using SEM imagery / Impoco G. et al. // Minisymposium: Image Analysis Methods for Industrial Application. Communications of the SIMAI. 2006. URL: http://citeseerx.ist.psu.edu/viewdoc/ download?doi=10.1.1.619.5750\&rep=rep1\&type $=$ pdf

10. Perspektivy skanerometrii v otsenke poristosti gubchatykh izdeliy / Savvin P. N. et al. // Trudy BGTU. Khimiya, tekhnologiya organicheskikh veshhestv i biotekhnologiya. 2014. Vol. 4 (168). P. 81-83.

11. Konyukhov A. L. Rukovodstvo k ispol'zovaniyu programmnogo kompleksa ImageJ dlya obrabotki izobrazheniy: handbook Tomsk: TUSUR, 2012. 105 p.

12. Kostin V. N., Tishina N. A. Statisticheskie metody i modeli handbook. Orenburg: GOU OGU, 2004. 138 p.

Petrusha Oksana, PhD, Associate Professor, Department of Foodstuff Expertise, National University of Food Technologies, Kyiv, Ukraine, e-mail: petrushaoo@ukr.net, ORCID: https://orcid.org/0000-0002$6009-127 X$

Daschynska Olga, Department of Foodstuff Expertise, National University of Food Technologies, Kyiv, Ukraine, ORCID: https:// orcid.org/0000-0003-0710-5043

Shulika Alina, Department of Foodstuff Expertise, National University of Food Technologies, Kyiv, Ukraine, e-mail: shulika.alina.97@gmail.com, ORCID: https://orcid.org/0000-0002-3333-2103 